\title{
Colonial Houses and Cultural Identity in New York State's Mohawk River Valley
}

\author{
Scott Stull1, Michael Rogers ${ }^{2}$, Kevin Hurley ${ }^{3}$ \\ ${ }^{1}$ Department of Sociology-Anthropology, State University of New York at Cortland, Cortland, USA \\ ${ }^{2}$ Department of Physics and Astronomy, Ithaca College, Ithaca, USA \\ ${ }^{3}$ Geometrics Inc., San Jose, USA \\ Email: mrogers@ithaca.edu
}

Received 17 January 2014; revised 18 February 2014; accepted 25 February 2014

Copyright (C) 2014 by authors and Scientific Research Publishing Inc.

This work is licensed under the Creative Commons Attribution International License (CC BY).

http://creativecommons.org/licenses/by/4.0/

(c) (i) Open Access

\begin{abstract}
In the mid-eighteenth century, the Mohawk River Valley was the colonial frontier in New York, and different social, political, and cultural groups were creating their identity through action and material culture, including the built environment. Two houses, built in 1749 and 1750, are compared in relation to identity and social position of their owners. The landscape was investigated using archaeogeophysics and targeted excavation to determine how the houses and their landscapes expressed cultural identity in colonial New York. The houses and landscapes reveal how specific identities were created by the owners of the houses as part of their efforts to improve their social, political, and economic standing on the frontier while also providing a defensive structure in the face of potential French raids into the region.
\end{abstract}

\section{Keywords}

Mohawk Valley; Colonial America; GPR; Earth Resistance; Magnetometry; Built Environment

\section{Introduction}

In the eighteenth century, the central Mohawk Valley was New York’s colonial frontier (Venables, 1967: p. 7). British colonial expansion was being contested by the French based in western New York and Canada. Dutch colonists from the Hudson River Valley and eastern Mohawk were moving west away from British dominion (Kammen, 1975: pp. 149-151), and Palatine Germans seeking land were being placed as a buffer against French invasion by the British colonial government (Kammen, 1975: pp. 177-178; Otterness, 2004: p. 71). British settlers were also establishing themselves in the region, extending the British colonial enterprise to these new lands. Among these EuroAmerican settlers remained villages of the Mohawk Nation of the Haudenosaunee (Iroquois) 
confederacy, who ceded lands to the newcomers mainly by treaty and sale, while retaining some lands for themselves (Otterness, 2004: pp. 11-120). The threat of French attack or invasion, as occurred in the end of the seventeenth century as far east as Schenectady (Kammen, 1975: pp. 143-145), led to the construction of forts and fortified houses, mainly of stone and often with palisades surrounding them. The central Mohawk Valley was the site of a series of French raids during the French and Indian War in the mid-1750s, substantiating the need for defense (Venables, 1967: pp. 24-27).

In 1749 and 1750, two fortified houses were built about 25 miles apart on the north side of the Mohawk River (Figure 1). One was Fort Johnson, the third house built by William Johnson, later Sir William Johnson, Super-

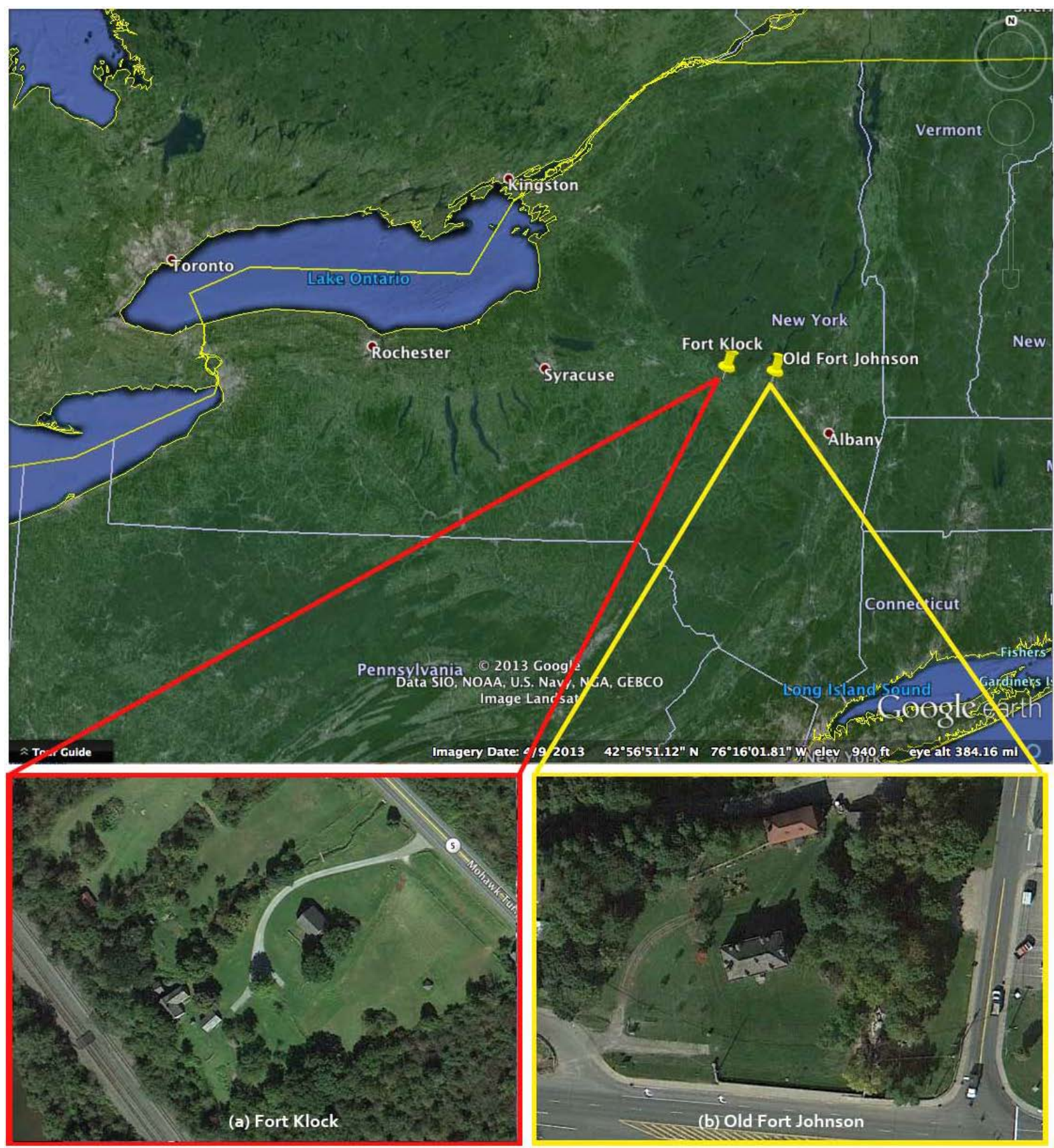

Figure 1. Locations of (a) Fort Klock and (b) Old Fort Johnson along the Mohawk River northwest of Albany, New York, and views of the sites in aerial photographs. Images courtesy of Google (Digital Global, SIO, NOASS, US Navy, NGA, GEBCO, Landsat). 
intendent of Indian Affairs for the Northern Region. The second was Fort Klock, built by Johannes Klock, a German-Dutch trader. Both structures were stone, fortified houses, built to display a specific status in this mixed social context, and served as strong points for defending the residents and neighboring settlers in case of attack. Despite their functional similarity, date of construction, and nearby location, these two houses are markedly different in appearance and spatial organization. The houses were built to create a cultural identity for each owner, and those cultural identities were quite different.

Cultural identity on the colonial frontier was a fluid, self-fashioned construction (Upton, 1996). The presentation of identity was crucial in this contested environment, and was not simply an extension of a static ideal from the Old World. For both William Johnson and Johannes Klock, they actively presented an identity they wanted other people to see, and their houses were part of that construction.

The archaeological study initiated in 2009 had the goal of exploring the use of space around these two houses to discover what was done in this arena of the built environment related to the construction of cultural identity on the frontier. Documentary sources reveal that there was a walled area in front of Fort Johnson, but how that space was laid out or used was unclear. Small-scale archaeological testing revealed the presence of limestone pavers, so a paved courtyard seemed possible. Similar cobbled surfaces have been found at other colonial houses, such as Sylvester Manor in southeastern New York (Hayes, 2007: pp. 44-46; Kvamme, 2007: pp. 51-70) or Sir William Johnson's later home, Johnson Hall in Johnstown, NY. At Fort Klock, there was no documentary or archaeological evidence exploring the landscape, but there was an oral history suggesting a wooden palisade had once surrounded the house. To investigate the landscape of the houses, a combined archaeogeophysical (Gaffney \& Gater, 2003; Rogers, 2011) and excavation strategy was employed to gain a better understanding of this aspect of the creation of cultural identity on New York's colonial frontier.

\section{Old Fort Johnson}

William Johnson, though born in Ireland, was part of the British colonial elite. Using family connections within the colonial power structure, Johnson positioned himself as an invaluable member of the elite on the colonial frontier (Venables, 1967: pp. 12-17). Johnson was particularly skilled at establishing ties to the Mohawk Nation (Venables, 1967: p. 14), and hosted councils between them and the British at his home at Fort Johnson. Johnson used this relationship to eventually become the Superintendent of Indian Affairs for the Northern Region, the chief negotiator with all the Native Americans in the northern section of the British colonies in America. Johnson also used his connections and wealth to become a leader during the French and Indian War. As a result of his actions, he was elevated to the status of baronet of colonial New York (Venables, 1967: pp. 20-22), achieving a status as high as any other person in British North America. Sir William Johnson was a member of the top of the British Colonial elite, and was living at Old Fort Johnson when he was elevated to his title of baronet.

The house Sir William Johnson built was the embodiment of his elite status (Figure 2). The structure is a central passage house with two rooms on either side of the passage, and had a full second floor with attic, and a working cellar. In this house, the attic was used, at least in part, for defense, with gun swivel mounts in the attic window frames. The remainder of the house was mainly used for domestic purposes. Additional structures, or outbuildings, provided space for other activities including industry with a mill and related buildings. The house faced the King's Road, which ran along the Mohawk River, and displayed a symmetric front façade to all who passed.

\section{Fort Klock}

Johannes Klock was the son of a Palatine German father and Dutch-American mother. Klock was a trader, catering to the Dutch, Palatines, and Native Americans who lived in the area or travelled up and down the Mohawk River. The Palatines were creating a specific identity as a "third nation" distinct from both the French and the English, but also European in origin (Otterness, 2004: pp. 154-160). Klock and his brothers, as leading members of the Palatine community, were rivals to William Johnson (Venables, 1967: pp. 36, 55), and tried to create an alternate model of European settlement to the British model displayed by Johnson.

Fort Klock, like Old Fort Johnson, still has the gun loops and thick stone walls of important houses of the mid-eighteenth century Mohawk Valley (Figure 3). It also faced the King's Road and the Mohawk River. However, Fort Klock is built on a river terrace, and access to the house from the road was accomplished by an access road up the slope, which led to the house being approached from the south. The southern gable of Fort Klock displays what is called "mousetooth" or tumbling masonry (Figure 4), a distinctive characteristic of 


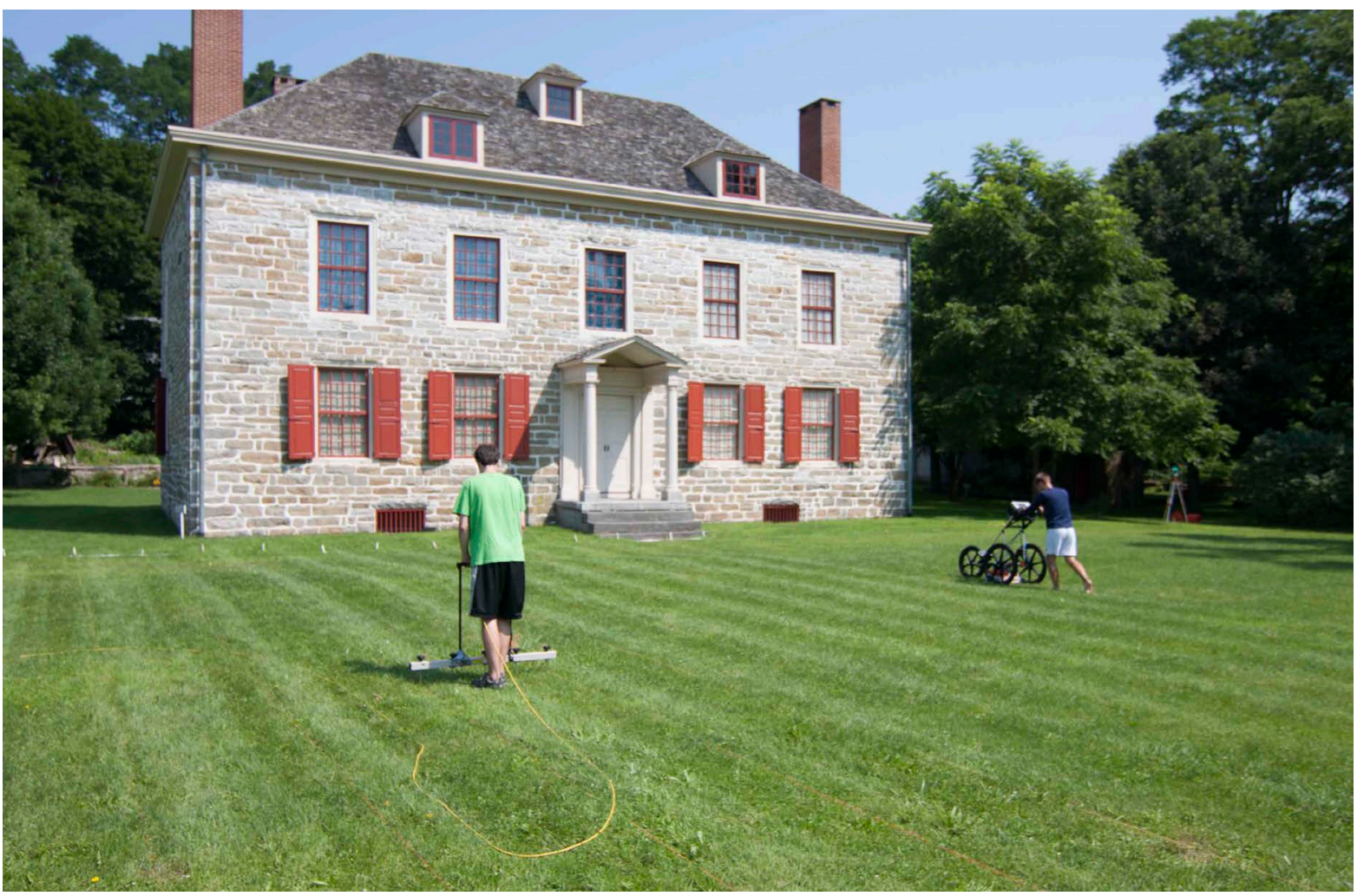

Figure 2. Old Fort Johnson taken from the south looking north.

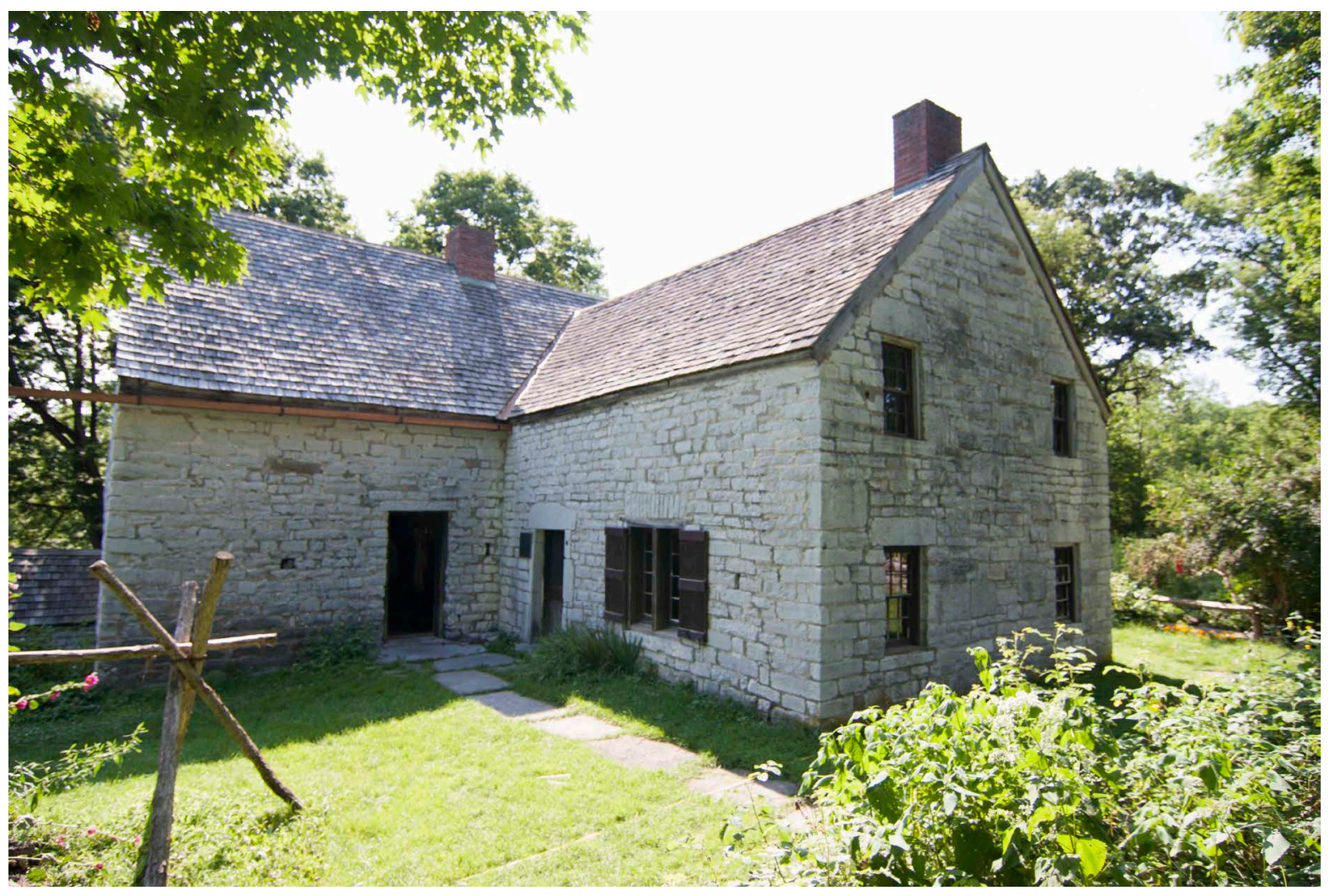

Figure 3. Fort Klock taken from the east looking west, originally the rear of the house. 


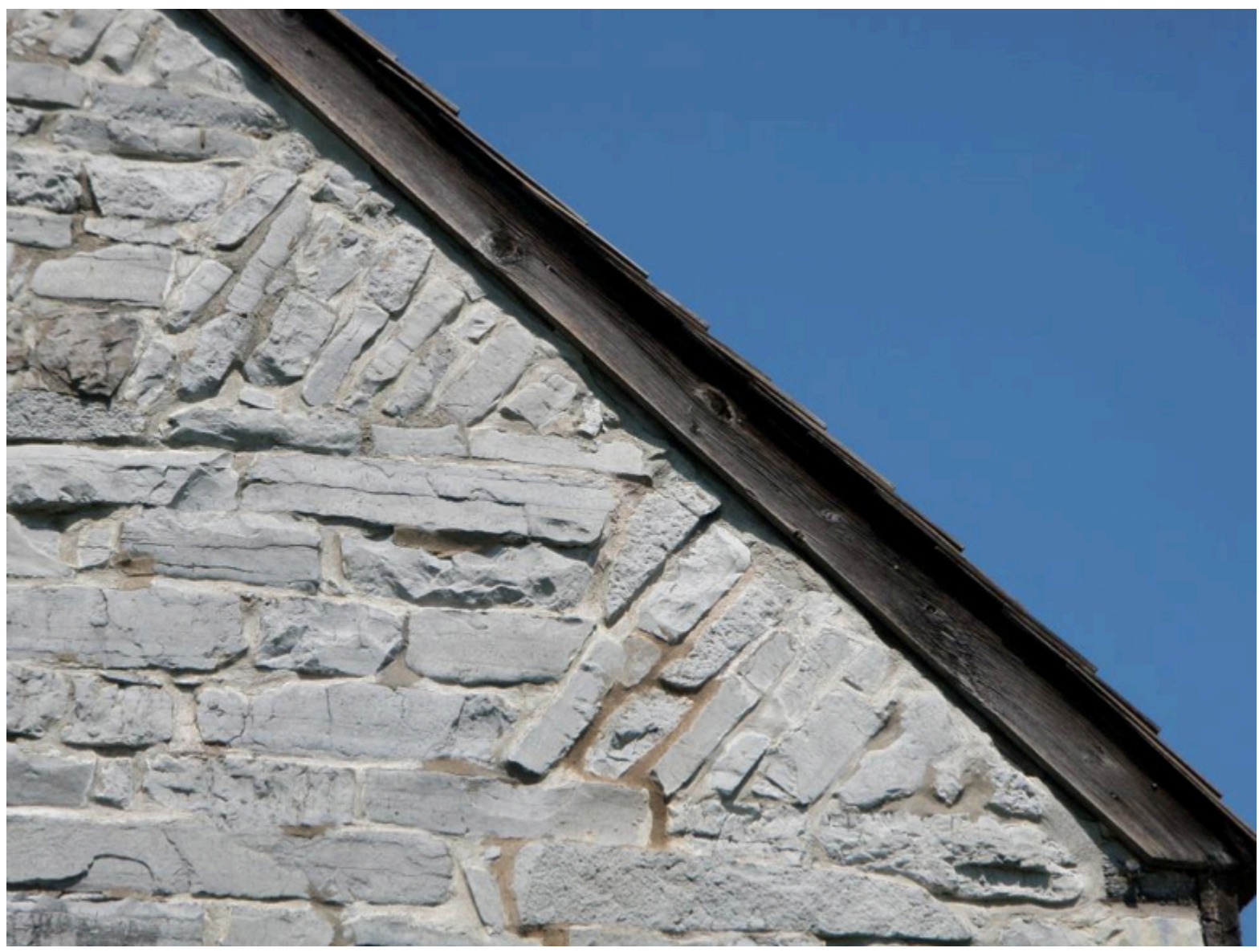

Figure 4. Dutch-influenced tumbling masonry on the south gable of Fort Klock.

Dutch construction (Stevens, 2005: p. 50). The northern gable, which faces a small creek with waterfalls, does not have this construction, but has plain courses of masonry. The house itself is one and a half stories, with two original rooms on the lower floor and two rooms under the roof on the second floor, plus a full basement. A later expansion added a third room in an ell off the back of the house. Like the Jonathan Hager House, a Palatine house in Maryland, Fort Klock has a spring and pool in one chamber of the basement, a recurring feature of Palatine houses (McMurray, 2011: p. 40). The interior of Fort Klock was restored in the mid-twentieth century so the precise layout and details are uncertain, but the layout appears to parallel that of the Mabie House, a Dutch house in the Eastern Mohawk valley built around 1706. The use of the house was mixed domestic and commercial, with one of the rooms of the house used as a trading post, also similar to the Jonathan Hager House in Maryland. Fort Klock also has two bearing beams supported by the chimney mass, typical of Palatine construction and markedly different from both English and Dutch construction of the mid-eighteenth century (Upton, 1981: p. 77). Like Old Fort Johnson, Fort Klock was built to display a specific status in this mixed colonial society. Klock was attempting to construct an identity distinct from the dominant political power, in part as a defensive measure in an effort to protect themselves from French attack, and also to appeal to the Dutch and German settlers who preferred to trade with someone other than the British.

\section{Archaeogeophysical Data Collection Methods}

Ground-penetrating radar, earth resistance, cesium magnetometry, and fluxgate gradiometry were used at selected areas of both sites (Figure 5). These different techniques each reveal a different kind of signature of past human activities, and the combined techniques can provide information that any single technique cannot (Kvamme, 2006, 2007: pp. 51-70). Targeted excavation units were placed to explore archaeogeophysical features with subsurface investigation. 


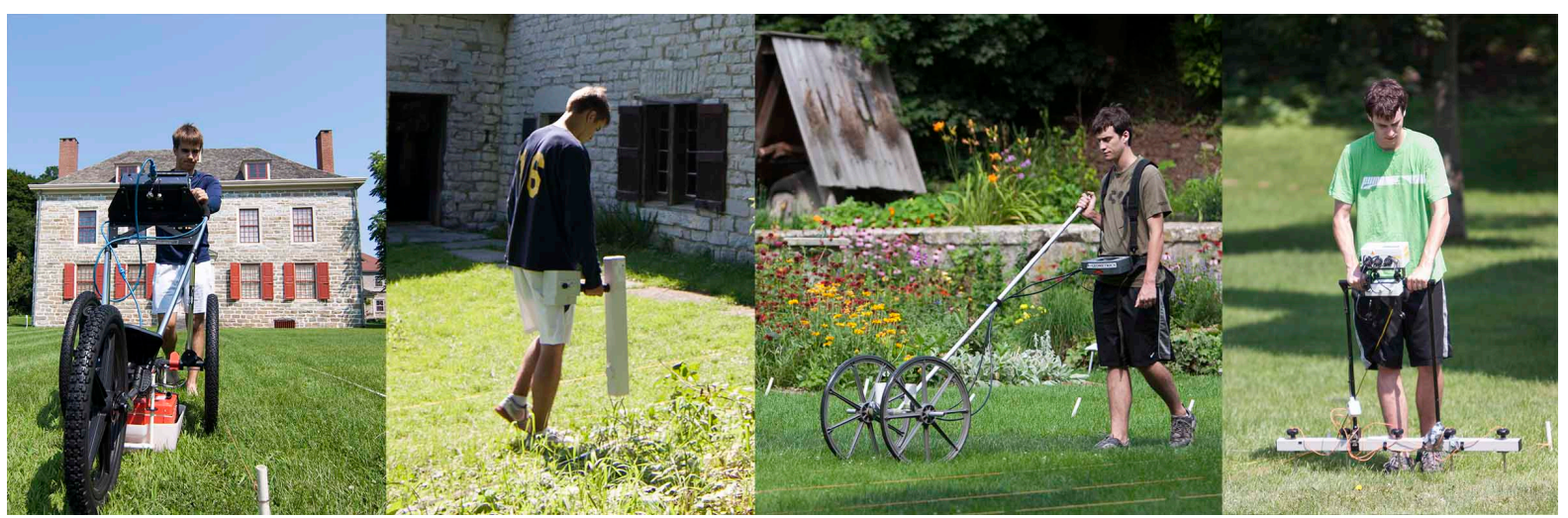

Figure 5. Archaeogeophysical instruments used at Old Fort Johnson and Fort Klock; from Left to Right: GSSI SIR 3000 GPR with $400 \mathrm{MHz}$ antenna, Geoscan FM256 Fluxgate gradiometer, Geometrics G-858 dual cesium gradiometer, Geoscan RM15 earth resistance meter with multiplexer.

The ground-penetrating radar (GPR) survey was conducted using a Geophysical Survey Systems, Inc. (GSSI) SIR-3000 ground-penetrating radar system and survey cart was used with a central antenna frequency of 400 MHz (Geophysical Survey Systems, Inc., 2009). The control unit was set at 100 scans per linear meter, which corresponds to a radar pulse into the ground every centimeter along the each transect with transects spaced 0.50 m apart. A time window of $30 \mathrm{nS}$ with 512 samples per scan was used, which corresponds to a reading taken every vertical $0.002 \mathrm{~m}$ down to a depth of approximately one meter.

The soil resistance survey was conducted using a Geoscan Research RM-15 with multiplexer Resistance Meter configured in the twin parallel probe array mode (Geoscan Research, 2009). The instrument has five mobile probes attached at the bottom, which are stuck into the ground, while two remote probes are set a fixed distance away. The mobile probes are inserted into the soil every $0.50 \mathrm{~m}$ along each transect. In the twin parallel array mode with five mobile probes are fixed to the instrument four soil resistance readings are recorded at $0.25 \mathrm{~m}$ intervals between the probes. The sensing depth is dependent on the spacing of each mobile probe, where the greater the distance between probes correlates with a greater signal depth.

The fluxgate gradiometry survey was conducted using a Geoscan FM 256 fluxgate gradiometer (Geoscan Research, 2004). The instrument samples at a rate of 16 data points per second, resulting in a data point every 0.06 $\mathrm{m}$ along each transect with transect lines spaced $0.25 \mathrm{~m}$ apart. This gives us a total of 25,600 data points in a 20 $\mathrm{m} \times 20 \mathrm{~m}$ grid unit. The sensors are fixed at $0.50 \mathrm{~m}$ apart in a vertical gradient. The fluxgate gradiometer has two sensors, orientated perpendicular to the ground, that take a reading which are then subtracted from each other to measure the change in the strength of the magnetic field at each point.

The cesium magnetometry survey was conducted using a Geometrics G-858 optically pumped magnetometer system (Geometrics Inc., 2001). The two sensors were spaced horizontally $0.25 \mathrm{~m}$ apart on a cart to cover two transects with each pass. The sampling rate was set to $10 \mathrm{~Hz}$ corresponding readings taken every $0.05 \mathrm{~m}$ along each transect at the chosen walking speed. All instruments gathered data using a bidirectional survey method where data were collected from south to north on the first transect and then north to south along the next transect with a continued alternating pattern.

\section{Archaeogeophysical Data Processing Methods}

All of the data were post-acquisition processed using standard processing methods (Aspinall, Gaffney, Schmidt, 2009; Conyers, 2004; Geoscan Research, 2005, Goodman, 2004; Schmidt, 2013; Scollar et al., 1990). The general processing steps are to 1 ) remove any dropped points, 2) remove large singles/spikes, 3) clip or range despike the data to remove signals larger than features of interest, 4) apply zero-mean-grid, which subtracts the mean value of the survey unit from all points to normalize the grid on zero (this step is not applied to the cesium magnetic data), 5) destagger to remove positional errors that arise from variable walking speeds, 6) apply an interpolation method to create an evenly spaced data set, 7) further edge-match all of the survey units, and 8) create an image plot mosaic of all survey units. Instead of items 1 and 2 above, GPR processing applies a gain to boost the intensity of deeper signals and applies a wobble correction that removes a drift in the signal as the ra- 
dar wave travels deeper into the ground (Hurley, 2011). The GPR data were processed entirely using GPR-Slice V7.0, the cesium magnetic data were processed using Geometrics's MagMap2000 V4.0 (2002), Microsoft Excel for Mac 2011, and Golden Software's Surfer 10.0, and the earth resistance and fluxgate gradiometer data were processed using Geoscan's Geoplot 3.0 and Surfer 10.0 (Golden Software, Inc., 2010). Figures 6 and 7 present the image plot results of the surveys at Old Fort Johnson and Fort Klock.

\section{Excavation}

Prior to this investigation, Old Fort Johnson has had limited archaeological investigations. In 1976, Lenig conducted a series of exploratory test units to identify subsurface features of the property (Mendel et al., 1977: pp. 44-54). Since then, the only work has been done prior to ground-disturbing activities as part of the preservation of the site. Fort Klock has not had any significant archaeological study, though a collection of material found while gardening exists at the Fort.

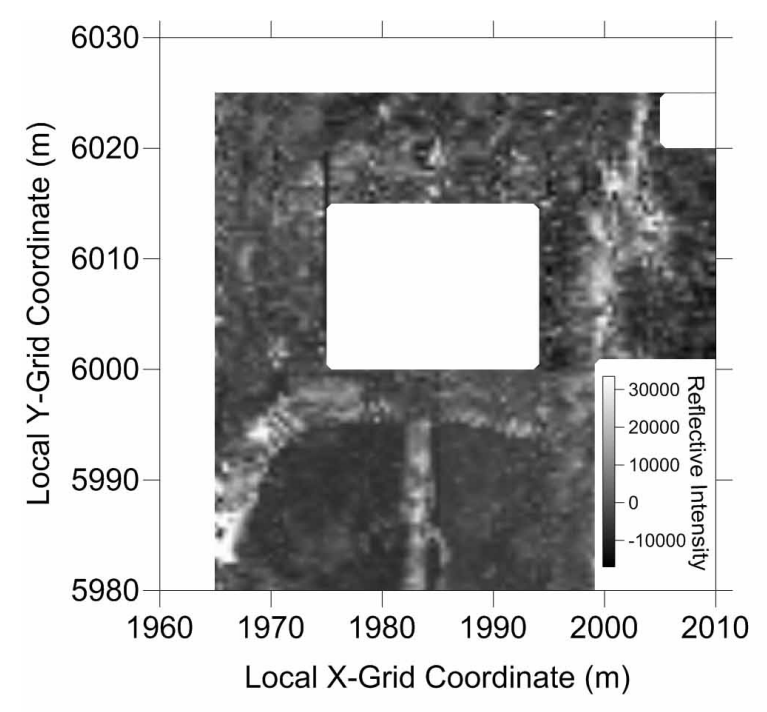

(a) GPR

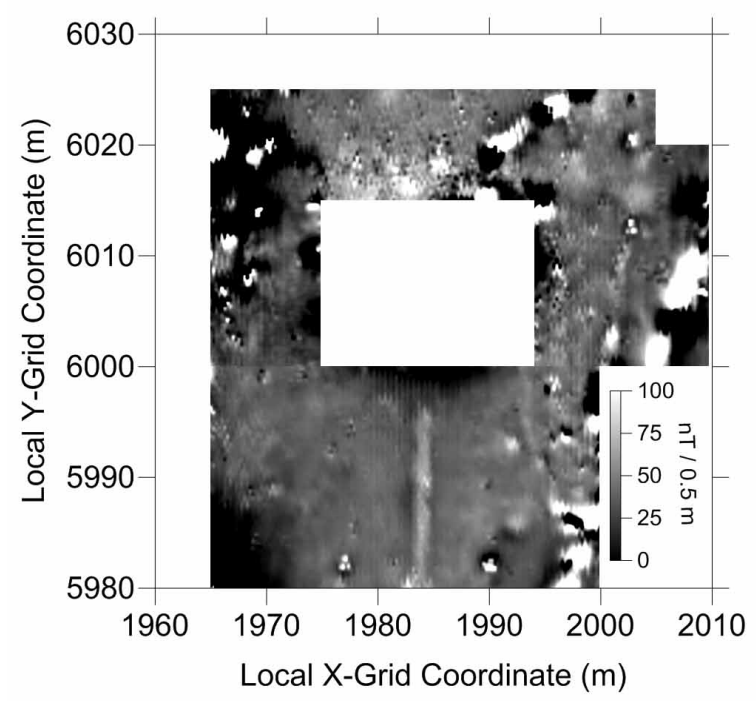

(c) Fluxgate Gradiometer

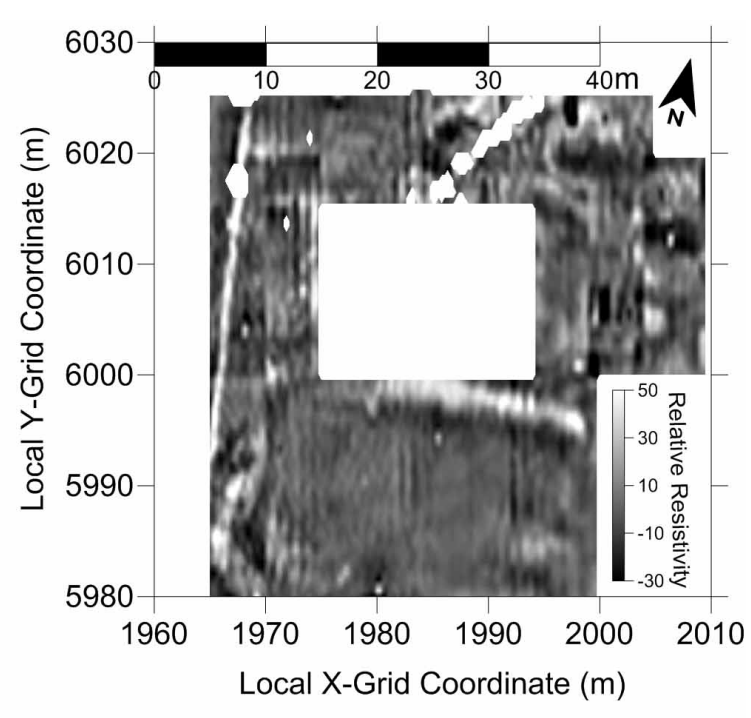

(b) Earth Resistance

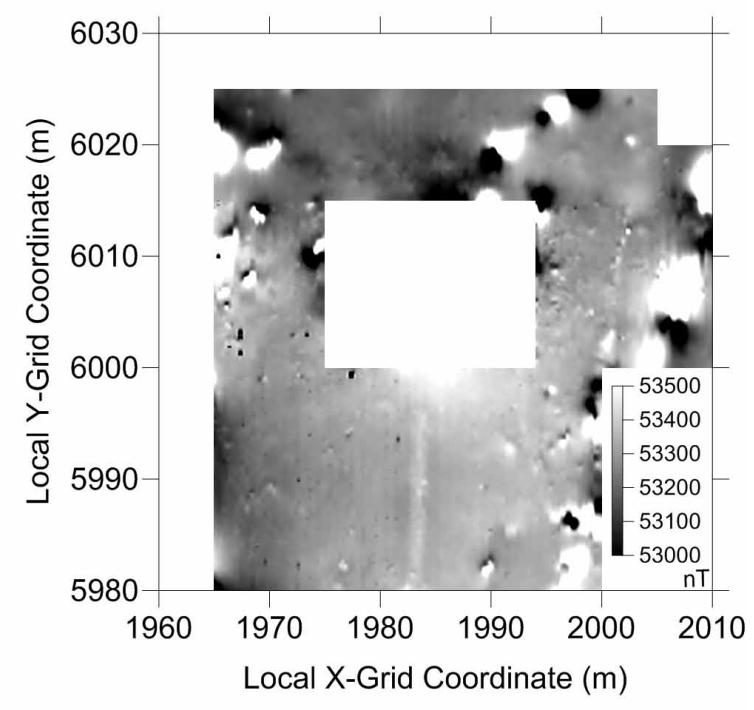

(d) Cesium Magnetometer

Figure 6. Archaeogeophysical data from Old Fort Johnson (a) GPR time slice from $29 \mathrm{~cm}$ - $37 \mathrm{~cm}$; (b) earth resistance; (c) fluxgate gradiometer; and (d) cesium magnetometer total field. 

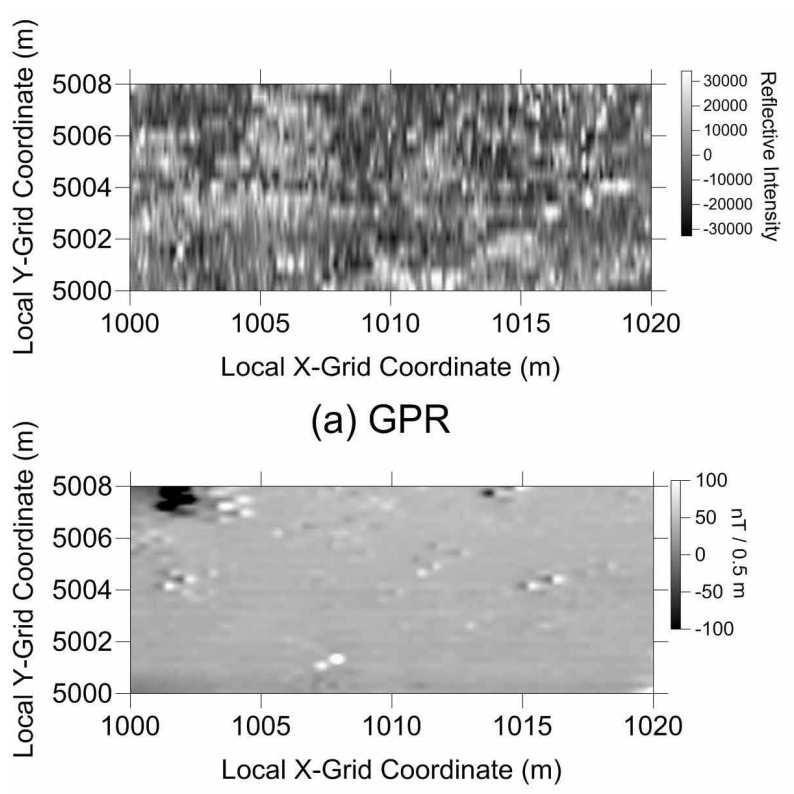

(c) Fluxgate Gradiometer

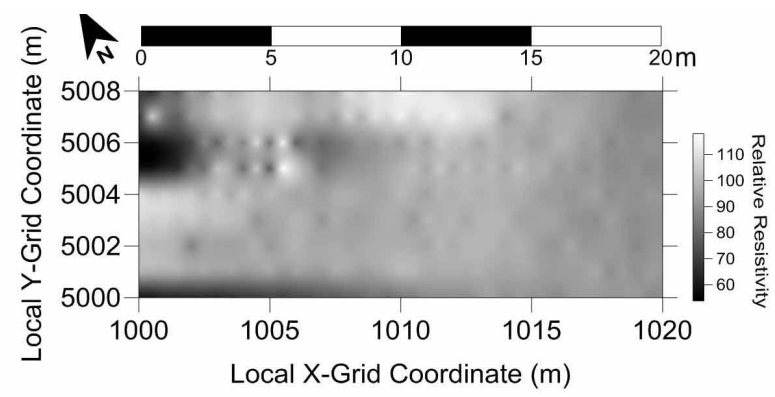

(b) Earth Resistance

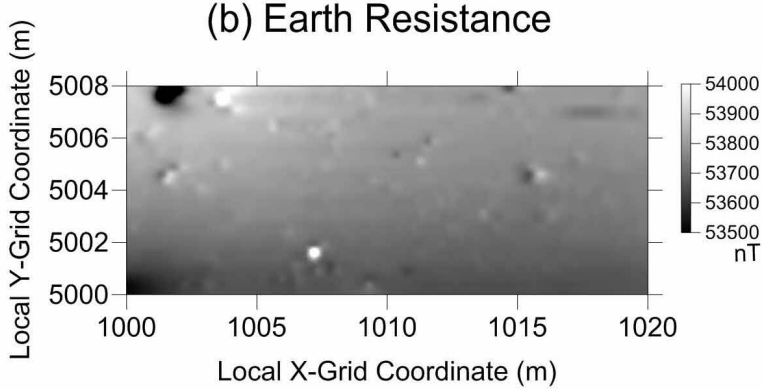

(d) Cesium Magnetometer

Figure 7. Archaeogeophysical data from Fort Klock (a) GPR time slice from 22 cm - 27 cm; (b) earth resistance; (c) fluxgate gradiometer; and (d) cesium magnetometer total field.

After the 2009 archaeogeophysical study, Stull directed targeted excavations placed to investigate specific subsurface features identified by the archaeogeophysical surveys and the historic record. Two units were excavated at Old Fort Johnson, and one was placed at Fort Klock. Standard archaeological techniques were followed, including stratigraphic excavation and screening of soils through $1 / 4$ inch mesh. Two $1 \mathrm{~m} \times 1 \mathrm{~m}$ units were placed in the front yard of Old Fort Johnson. One uncovered a remnant of the former pavement and what appears to be an early twentieth century pit, possibly associated with early re-enactors at Old Fort Johnson. The second unit found brick, stone, and mortar rubble, possibly from one of the outbuildings. Sir John Johnson's renovations to Old Fort Johnson may have included demolishing the outbuildings, and the rubble appears to have been brought to the same level as the courtyard pavement.

Unit 1 was placed over an archaeogeophysical feature consistent with a possible pit feature, and near the 1976 test hole 7 (Mendel et al., 1977). That 1976 excavation found a limestone pavement layer below a layer of sand, approximately 12 inches $(30 \mathrm{~cm})$ below the surface. A pavement layer was found in unit 1 on the east side of the unit $30 \mathrm{~cm}$ below the surface, but not in the rest of the unit. The remainder of the unit had mixed soil with artifacts, stones, and bone that extended to a depth of $70 \mathrm{~cm}$ below the surface.

Unit 1 was excavated in eight levels, and comprised three strata. It contained cultural material to the limit of excavation. Architectural debris was found in abundance, including brick fragments, stone, mortar, slate fragments, and window glass. Household material and food remains were found, and included bottle glass fragments, ceramic tableware including creamware and gray salt-glazed stoneware, utilitarian ceramics including redware, and bones and shells. Notable among the bones were some large mammal bones, either oxen or beef, which had been sawn. The use of saws to cut bones during food processing arose after the colonial era in the United States. A copper alloy plate, approximately the size of a shoe heel, was recovered. Pipe stems and bowl fragments were found. A small quantity of lithic debitage, probably from a prior Native American habitation at the site but possibly from maintaining gun flints, was also found.

Unit 2 was placed on the west side of the central axis of the house to test for the presence of outbuildings based on the projected plans created for the historic structures report (Mendel et al., 1977). The 1976 archaeological study found a foundation remnant close to the house (Test Hole 2), and additional structures were expected to create a forecourt similar to that seen at Johnson Hall. The archaeogeophysics survey did not indicate any specific outlines for foundation remnants, so the historic architect plans were projected onto the landscape in an effort to test those plans through excavation. Unit 2 was laid out at the location of one of the corners of the projected buildings (Mendel et al., 1977: p. 42) to see if the projected location was accurate. Unit 2 aligned with 
an area of scattered GPR reflections.

Unit 2 was excavated only to a depth to test for the presence of the pavement as found in Test Hole 8, which should have been at approximately $30 \mathrm{~cm}$ (12 inches), or a foundation at a similar depth. One paving stone was found in a corner of the unit at approximately $40 \mathrm{~cm}$, but the remainder of the unit contained stone and brick rubble, not pavement. No foundation remnants were located. Time constraints prevented further excavation at this location.

Unit 2 was excavated in three levels and contained two strata. The majority of the recovered material was architectural debris, including brick, mortar, stone, nails, and window glass. Pipe fragments and household debris were found in smaller quantities. One fragment of tin-glazed earthenware was the only example found at Old Fort Johnson during these excavations, typically used before 1750 so its absence is not unexpected. Three rodent bones, probably rat, were found. Lithic debitage was also found, like in Unit 1 . One piece appeared to be a blade core fragment that had been used as a cutting or scraping tool with unifacial flaking along the edges. This piece is scratched, possibly from contact with the architectural debris during the demolition of the outbuildings.

One unit was placed in the front of Fort Klock to identify a linear GPR feature suggestive of a palisade or pathway. The same standard archaeological techniques were used at Fort Klock as were used at Old Fort Johnson. Unit 1 was excavated to a depth of approximately $60 \mathrm{~cm}$ below the ground surface. At approximately $50 \mathrm{~cm}$ below the surface, Feature 1 was found, consisting mainly of ash along the west wall. This ash deposit was in the same location as the feature found in the GPR data. The top of the ash had pearlware sherds, dating to the late eighteenth or early nineteenth century (Miller, 2000: pp. 12-13). The upper levels of the unit contained lenses of burned wood ("charcoal”) and soil discolorations where soils had been partially mixed. Also of note were numerous quartz crystals, or Herkimer diamonds. Herkimer Diamonds are naturally-faceted rock crystals of almost pure quartz that are transparent and colorless, though with occasional iron staining. These were trade objects in the colonial period (Moody, 2003), and originate in the central Mohawk Valley. According to Dave Klock, one of the board members of Fort Klock Restoration, Herkimer diamonds are not normally found in the soil at the site, indicating that these may be left from the colonial trade at the site. Excavation was stopped due to time constraints.

Unit 1 was excavated in six levels comprised of two strata. Architectural debris, mainly brick fragments and nails with some window glass, was abundant. Approximately one hundred quartz fragments and Herkimer Diamond crystals or broken crystals were recovered from Unit 1 (Figure 8), along with a slightly lesser quantity of

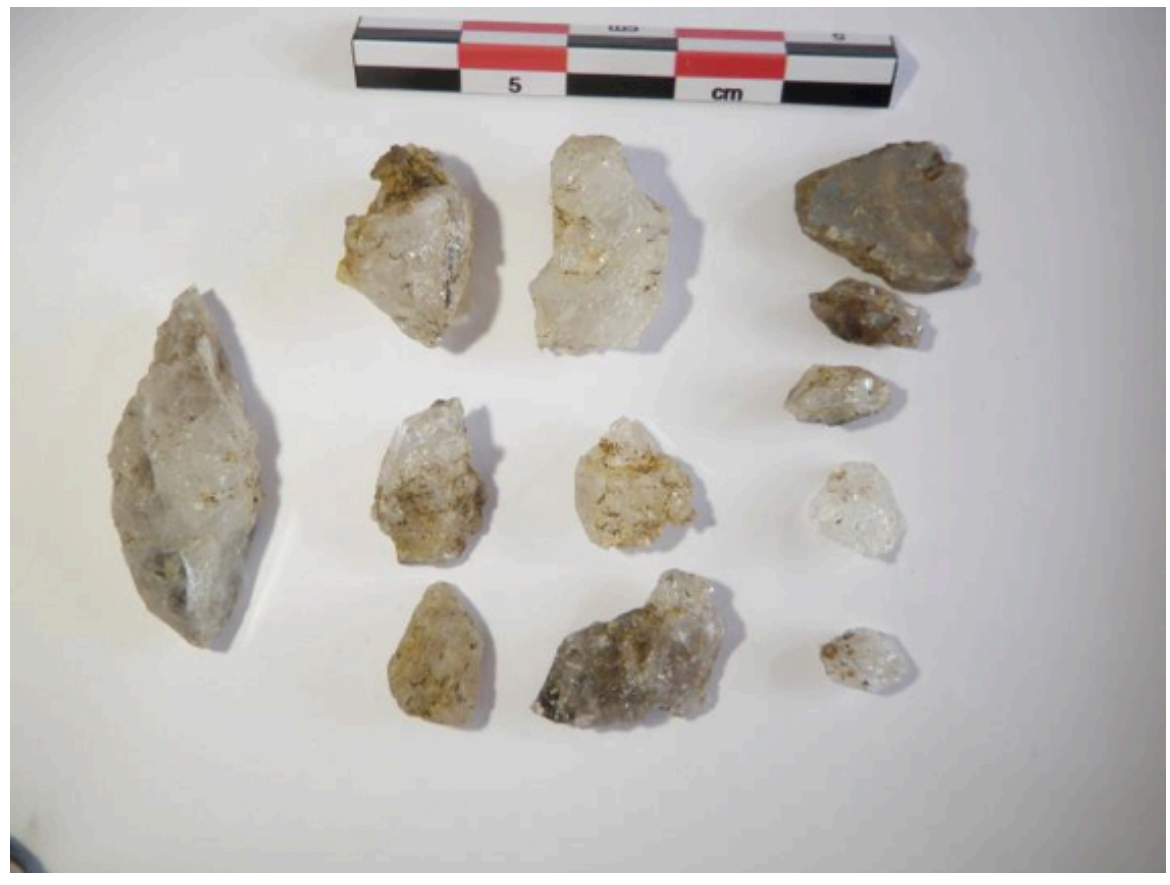

Figure 8. Herkimer diamond and other quartz fragments recovered from Fort Klock. 
stone debris from processing the quartz from its surrounding matrix. Most of the Herkimer Diamonds are small, broken, or discolored. A ceramic triangular object, interpreted as a bead blank, was found in Level 6, either lost or discarded during manufacture. Household debris, including pipe fragments, creamware, pearlware, and salt-glazed stoneware were recovered. Food remains were represented by shells and bone, including ten teeth indicating animal heads were processed at the site.

\section{Interpretations}

Figures 9 and 10 present a combined interpretation from the 2009 investigations at Old Fort Johnson and Fort Klock. Old Fort Johnson originally had a straight walkway running from the front door out to the old colonial road (Figure 9(D)). That walkway was replaced by a curved driveway thus creating a new approach to entering the house (Figure 9(C)). Additional paths lead from the curved driveway to what is now the visitor center with branches leading off to the creek (Figure 9(A)). The two magnetic features to the south of Old Fort Johnson

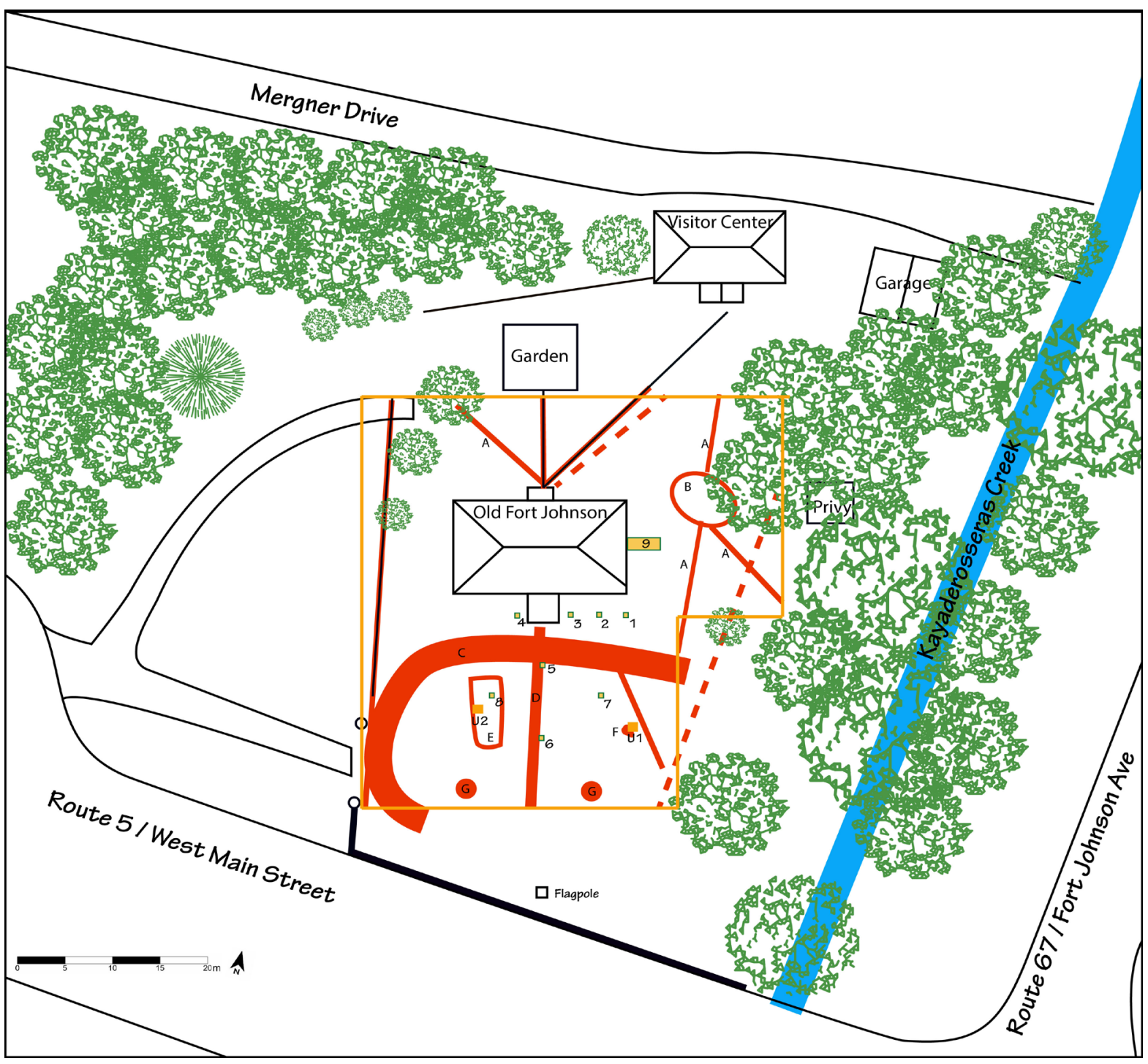

Figure 9. Combined drawing of the modern features, archaeogeophysical and excavation unit locations, and interpretation of archaeogeophysical data. Squares labeled 1-9 are from the 1976 excavations by Lenig. U1 and U2 are the 2009 excavations by Stull. Red dashed lines are modern utilities identified by the archaeogeophysical surveys. Solid red lines are archaeogeophysical features: A) pathways; B) curved pathway; C) curved driveway; D) walkway; E) scattered GPR reflections; F) GPR reflection consistent with a pit; and G) location of 1976 ceremonial canon mounts. 
(Figure 9(G)) are buried support mounts where replica canons were placed during the 1976 United States Bicentennial celebrations. Excavation Unit 1 confirmed the location for a pit dug during the early twentieth century (Figure 9(F)), likely for one of the historical pageants put on when Old Fort Johnson became a museum. Scott Haefner, caretaker for Old Fort Johnson, suggested it could be an ox-roasting pit; the large cow bones with saw cuts recovered from the unit would be consistent with that interpretation. Unit 2 is interpreted as a rubble scatter from an outbuilding, based on the brick fragments, nails, window glass, and rodent bones (Figure 9(E)). This is consistent with the documentary record, particularly the 1759 Guy Johnson drawing of Old Fort Johnson, and the scatter of archaeogeophysical features in that vicinity. That outbuilding was demolished and leveled to a similar height to the paving found elsewhere on the front of the house. One possibility is that it occurred with the remodeling done by Sir John Johnson after he acquired the house (Mendel et al., 1977: p. 15), but that cannot be proved or disproved at this time. There is no indication this is a corner of the outbuilding, showing the model presented in the architectural reconstruction (Mendel et al., 1977: p. 42) needs modification.

The investigation at Fort Klock was more limited in scope to Old Fort Johnson due to more modern features and alterations of the landscape. The GPR data contain a reflection from a mostly linear feature approximately $25 \mathrm{~cm}$ beneath the ground surface (Figure 10(A)). The excavation unit placed over this GPR feature suggests

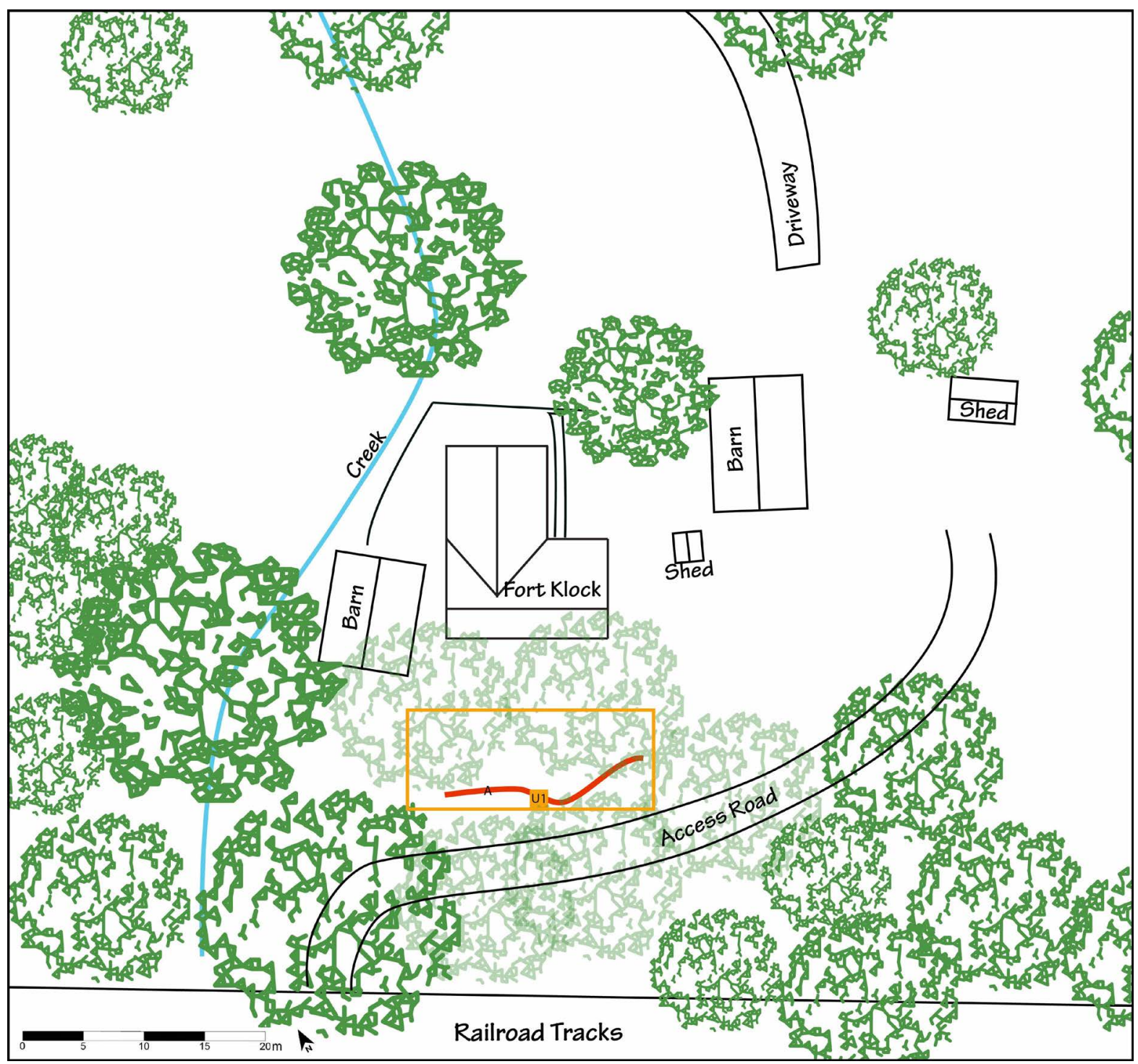

Figure 10. Combined drawing of the modern features, archaeogeophysical and excavation unit location, and interpretation of archaeogeophysical data. Solid red line (A) is an archaeogeophysical feature. 
that Fort Klock had a wooden palisade constructed during the colonial period, and after the War of 1812, the palisade was removed and burned. During that conflict, no military action took place in the Mohawk Valley, so the additional defenses of a wooden palisade, now likely in poor condition, would not be needed. It is also possible that the palisade was removed at the end of the American Revolution, and the pearlware was deposited later. The location of the feature, the presence of mouse-tooth masonry of the south gable but not the north gable, and the existing access path to the river bed, reveals that access to the house came up the slope in front of the house and to the south, creating a specific orientation to the house and landscape. It is also apparent that the space in front of the house was an active work yard, and Herkimer Diamonds were apparently processed here by being removed from their matrix. Small, discolored, or broken crystals were discarded along with quartz that did not make large clear crystals. The presence of pearlware is an indicator of the continued active use of the site into the nineteenth century.

\section{Conclusions}

Both Old Fort Johnson and Fort Klock were built to express a specific cultural identity. Old Fort Johnson was used by William Johnson to project an elite English identity, despite his Irish birth. Fort Klock was used to project both a Dutch and Palatine German cultural identity for Johannes Klock. Each house supported the social agenda for its owner. Johnson was elevated to the colonial nobility while living at Old Fort Johnson, and Klock was a successful trader with both Native Americans and local residents who included a significant number of non-English colonists. The landscapes around the house were part of the construction of identity through material culture and the built environment. This archaeological investigation revealed that the landscapes around the two houses were as distinct as the houses, and contributed to the construction of the owners' identities in a contested frontier environment.

The material culture of the two sites representing the colonial era is quite similar. Both contained creamware and small pieces of other wares, including grey salt-glazed stoneware, porcelain, buff earthenware, and redware. Both had similar quantities of pipe fragments, and the food remains of bone and shell were comparable. Architecturally, both sites had brick, nails, and roofing slates. The brick is probably from the demolition or replacement of chimneys, but Old Fort Johnson had much more mortar, probably associated with the demolition of the outbuildings. Both sites had window glass, showing that glass was used fairly widely on the frontier at houses of substance like both Old Fort Johnson and Fort Klock.

The landscapes in front of each house serve as an indicator of social practice and behavior in the same manner as the houses themselves. The area in front of Old Fort Johnson was a working yard, but was created by a formal pavement and outbuildings which contained at least some aspect of the work performed there. The elite status of William Johnson was supported by the construction of an ordered landscape, parallel to the construction of an ordered society. At Fort Klock, the palisade appears to have served as a backdrop for working, but the work conducted in the working yard was visible to those in the houselot and the front of the house, including those entering the house through the palisade. At Fort Klock, the identity created by the form of the house and the use of the yard was purposefully and distinctly different from the English elite. Johannes Klock was appealing to the Dutch, German Palatine, and Native American inhabitants of the region. The activities pursued in and around the house, and the built environment in which it took place, were constructed to establish a different kind of presence. The material goods, the fortified nature of the house and enclosing defenses, and the very fabric of the buildings were the same at Old Fort Johnson and Fort Klock, but the identity and status of the two owners and houses were deliberately and distinctly different.

\section{Acknowledgements}

The authors would like to thank the support of the Montgomery County Historical Society and Fort Klock Restoration for their enthusiastic support for this research, and the Robert L. Funk Foundation for financial support. Taylor Boyd assisted with the archaeogeophysical surveys, and the archaeological excavations were conducted by Brant Venables, Michael Spears, and Silene Binkerd-Dale.

\section{References}

Aspinall, A., Gaffney, C. F., \& Schmidt, A. (2009). Magnetometry for Archaeologists. Walnut Creek: AltaMira Press. Conyers, L. B. (2004). Ground-Penetrating Radar for Archaeology. Walnut Creek: AltaMira Press. 
Gaffney, C. F., \& Gater, J. (2003). Revealing the Buried Past: Geophysics for Archaeologists. Stroud: Tempus Publishing. Geometrics Inc. (2001). G-858 MagMapper Operation Manual 25309-OM REV. D. San Jose: Geometrics, Inc. Geometrics, Inc. (2002). MagMap2000 4.0, User Guide. San Jose: Geometrics, Inc.

Geophysical Survey Systems, Inc. (2009). SIR System 3000 Manual. Salem: Geophysical Survey Systems, Inc.

Geoscan Research (2004). Fluxgate Gradiometer FM256 Instruction Manual. Version 1.6.

Geoscan Research (2009). Resistance Meter RM15-D Instruction Manual. Version 2.98.

Golden Software, Inc. (2010) Surfer 10 User's Guide: Contouring and 3D Surface Mapping for Scientists and Engineers. Golden: Golden Software, Inc.

Goodman, D. (2004). GPR-SLICE. Ground Penetrating Radar Imaging Software. User's Manual. California: Geophysical Archaeometry Laboratory.

Hayes, K. H. (2007). Field Excavations at Sylvester Manor. Northeast Historical Archaeology, 36, 34-50.

Hurley, K. (2011). Archaeogeophysical Survey of an 18th Century Manor House in the Mohawk River Valley. B.S. Thesis, Ithaca: Ithaca College.

Kammen, M. G. (1975). Colonial New York: A History. Oxford: Oxford University Press.

Kvamme, K. L. (2006). Integrating Multidimensional Geophysical Data. Archaeological Prospection, 13, 57-72. http://dx.doi.org/10.1002/arp.268

Kvamme, K. L. (2007). Geophysical Explorations at Sylvester Manor. Northeast Historical Archaeology, 36, 51-70.

McMurry, S. (2011) Rural Houses. In S. McMurry, \& N. Van Dolsen (Eds.), Architecture and Landscape of the Pennsylvania Germans, 1720-1920 (pp. 32-65). Philadelphia: University of Pennsylvania Press.

Mendel, Mesick, Cohen Architects (1977) Fort Johnson: Historic Structures Report. Washington DC: US Department of the Interior.

Miller, G. (2000). Telling Time for Archaeologists. Northeast Historical Archaeology, 29, 1-22.

Moody, K. (2003). Traders or Traitors: Illicit Trade at Fort Orange in the Seventeenth Century. In C. L. Fisher (Ed.), People, Places and Material Things: Historical Archaeology of Albany. Albany, NY: New York State Museum Bulletin 499.

Otterness, P. (2004). Becoming German: The 1709 Palatine Migration to New York. Ithaca, NY: Cornell University Press.

Rogers, M. (2011). Ch. 8: Archaeological Geophysics: Seeing Deeper with Technology to Compliment Digging. In M. Seddon, H. Roberts, \& R. V. N. Ahlstrom (Eds.), Archaeology in 3D: Deciphering Buried Sites in the Western US. Washington DC: SAA.

Schmidt, A. (2013). Earth Resistance for Archaeologists. Lanham: AltaMira Press.

Scollar, I., Tabbagh, A., Hesse, A., \& Herzog, I. (1990). Archaeological Prospecting and Remote Sensing. Cambridge: Cambridge University Press.

Stevens, J. R. (2005). Dutch Vernacular Architecture in North America, 1640-1830. West Hurley, NY: The Society for the Preservation of Hudson Valley Vernacular Architecture.

Upton, D. (1981). Traditional Timber Framing. In B. Hindle (Ed.), Material Culture in the Wooden Age (pp. 35-96). Tarrytown, NY: Sleepy Hollow Press.

Upton, D. (1996). Ethnicity, Authenticity, and Invented Traditions. Historical Archaeology, 30, 1-7.

Venables, R. W. (1967). Tryon County, 1775-1783, a Frontier in Revolution. Ph.D. Dissertation, Nashville, TN: Vanderbilt University. 